
\title{
CIÊNCIANATURA
}

\section{Phytochemical and phytotoxic investigation of the aqueous leaf extract of Eugenia dysenterica DC. under laboratory conditions}

Rafael Pozzi Malheiros, Ana Mapeli e Luciana Machado

Universidade Federal do Oeste da Bahia, BA, Brasil

\begin{abstract}
The objective of this study was to carry out a phytochemical characterization of the aqueous leaf extract of Eugenia dysenterica DC., as well as to evaluate its phytotoxic potential on the germination and growth of Lactuca sativa L. and Zea mays L. under laboratory conditions. Concentrations of 250,500,1000, 2000 and $4000 \mathrm{mg} / \mathrm{L}$ of the extract in addition to the control were used for the bioassays. Under laboratory conditions this extract inhibited average growth of the radicle/primary root and hypocotyl/coleoptile leaves of lettuce and maize, with proportionality between the effect and the concentration being observed. The presence of phenols, hydrolysable tannins, flavonols, flavanones, flavanonols, xanthones, flavones, free steroids and saponins were identifiedin the aqueous extract. The aqueous extract of the plant species under study has a phytotoxic effect, and this effect is due to the presence of phenolic compounds, tannins, flavonoids and saponins.
\end{abstract}

Keywords: Cagaita; Inhibition; Secondary metabolites 


\section{Introduction}

Allelopathy can be defined as the ability of plants to interfere in the germination and growth of neighboring plants through phytochemicals released into the environment (FERNANDEZ et al., 2016). This effect is mediated by substances belonging to different categories of secondary metabolites associated with protective functions in plants (SAMPAIO et al., 2016), among them essential oils, phenolic compounds and alkaloids (WANDSCHEER \& PASTORINI, 2008). These compounds (also known as allelochemicals) can affect other plants once released into the environment by promoting changes both at a cellular and metabolic levels, including changes in membrane permeability, nutrient absorption, protein synthesis, stomatal opening, photosynthesis and respiration (CHENG \& CHENG, 2015; FERREIRA et al. 2008).

Due to these changes, allelopathy is recognized as an important ecological process that can influence the structure and composition of native or cultivated plant communities (WANDSCHEER \& PASTORINI, 2008). Moreover, studies using allelopathy represent a good alternative for searching for new substances that can be used as natural herbicides and are less harmful to the environment (REIGOSA et al., 2013).

The Cerrado is the second largest biome in Brazil. The plant species found in this biome are usually subjected to constant metabolic stresses in response to environmental variations such as the scarcity of water and nutrients, and as a consequence these plants produce a variety of by-products as defense mechanisms (OLIVEIRA et al., 2004). As a result, many of these species are considered allelopathic (OLIVEIRA et al., 2004; PERIOTTO et al., 2004; OLIVEIRA \& CAMPOS, 2006), including the Eugenia dysenterica DC. Trees (Myrtaceae), for which it has been reported that its leaf extracts can reduce the initial growth of Lactuca sativa L. (lettuce) (GIOTTO et al., 2007), Zea mays L. (maize) (MALHEIROS et al., 2016), Sesamum indicum L. (sesame) and Raphanus sativus L. (radish) (PINA et al., 2009).

Although there are reports on the allelopathic potential of E. dysenterica under controlled laboratory conditions (GIOTTO et al., 2007, PINA et al., 2009, MALHEIROS et al., 2016), there is still no information in the literature that describes the compounds which are present in the aqueous leaf extract of the species found in the Cerrado Baiano, which may have a relationship with its allelopathic power over other plant species. In this sense, the present study aimed to characterize the class of secondary compounds present in the aqueous leaf extract of E. dysenterica, and relate them to the allelopathic potential of the species through growth bioassays with lettuce and maize under laboratory conditions.

\section{Materials and Methods}

The plant material (fully expanded leaves) of Eugenia dysenterica were collected from Serra da Bandeira (-12 $04^{\prime} 48^{\prime} \mathrm{S}$ and- $\left.45^{\circ} 00^{\prime} 36^{\prime \prime} \mathrm{W}\right)$, located in the municipality of Barreiras - Bahia. The area has Cerrado vegetation, exhibiting cerradão and ciliary forest physiognomies. The collection was performed in the morning at the end of August 2014, at which time the specimens were in the vegetative phenomephase.

To obtain the aqueous extract, the leaves were allowed to dry at room temperature for three days, and then they were ground in a blender and about $200 \mathrm{~g}$ were immersed in $1 \mathrm{~L}$ of distilled water. The solution was kept refrigerated at $10^{\circ} \mathrm{C}$ for 24 hours, avoiding fungus contamination. The material was subsequently filtered, frozen and lyophilized at $-35^{\circ} \mathrm{C}$. The extract was kept in a desiccator until the bioassays were performed. Five concentrations were used for the bioassays: 250, 500, 1000, 2000 and $4000 \mathrm{mg} \mathrm{L}^{-1}$, in addition to the control (distilled water).

Regarding germination and growth for the bioassays, lettuce and maize seeds obtained from a commercial establishment were selected by color uniformity and shape, and then treated with $2 \%$ sodium hypochlorite for two minutes to disinfest them against the presence of microorganisms. For lettuce bioassays, filter paper disks contained in previously autoclaved Petri dishes ( $9 \mathrm{~cm}$ in diameter) were impregnated with $2 \mathrm{~mL}$ of extracts or distilled water (control), and then 50 seeds were seeded onto each filter paper disk. A similar procedure was performed for the maize bioassays, however, the filter paper disks contained in Petri dishes $(15 \mathrm{~cm}$ in diameter) were moistened with $5 \mathrm{ml}$ of the test solutions and 25 seeds were later sown. The experiment was maintained in BOD germination chambers at controlled temperature and luminosity $\left(25 \pm 2^{\circ} \mathrm{C}, 230 \mu\right.$ moles $\left.\mathrm{m}^{-2 \mathrm{~s}-1}\right)$, according to a photoperiod of $16 / 8$ hours light/dark. The germination percentage was determined daily, considering the radicular protrusion of $2 \mathrm{~mm}$ (BRASIL, 2009).

The percentage of germinated seeds was calculated according to the methodology described by Labouriau and Valadares (1976) and the germination speed index (GSI) according to Maguire (1962):

$$
I V G=\frac{G 1}{N 1}+\frac{G 2}{N 2}+\ldots+\frac{G N}{N N}
$$


In which: G1, G2 and GN represent the number of normal seeds sprouted up to the nth day; N1, N2 and NN represent the number of days in which the germination was evaluated G1, G2 and GN.

The radicle/primary root and hypocotyl/coleoptile length were measured three days after root protrusion using a millimeter graph paper. The design was completely randomized with four replicates consisting of 25 or 50 seeds, depending on the target species, with ten seedlings for radicle/primary root growth and hypocotyl/coleoptiles growth.

In order to identify the main classes of secondary compounds, the aqueous leaf extract of $E$. dysenterica was subjected to qualitative tests that result in altering the coloration and/or formation of precipitates, characteristic for each class after the addition of specific reagents (MATOS, 2009). The presence of condensed and hydrolysable tannins, flavanols, flavanones, flavanonols and xanthones, anthocyanins, anthocyanidins and flavonoids, steroids and triterpenoids, saponins and quinones were investigated.

The results were submitted to analysis of variance (ANOVA), and the means were compared by the Scott Knott test at the $5 \%$ probability level using the Assistat 7.7 beta statistical analysis program (SILVA \& AZEVEDO, 2002).

\section{Results and Discussions}

No significant difference was observed between the concentrations of dry extract aqueous extract and the control regarding the germination percentage and the germination speed index of lettuce (Table 1). This same result was observed by Giotto et al. (2007), also using the aqueous extract of Eugenia dysenterica.

The aqueous extract of Cagaita also did not affect the germination of Sesamum indicum and Raphanus sativus (PINA et al., 2009). The extract of other species such as Ocimum basilicum L. (basil) (ROSADO et al., 2009), Lafoensia pacari A.St.-Hil. (Pacari) (MALHEIROS et al., 2014) were also not able to change lettuce germination. It can be seen that seed germination is generally little affected by the effects of plant extracts, and according to Ferreira \& Áquila (2000), allelopathic interference is more incident on seedling growth than on the germination phenomenon, due to the fact that this process is less sensitive to the action of allelochemicals/allelochemical substances.

The extract promoted significant inhibitory effects on lettuce radicular growth, regardless of concentration, with a mean decrease of $78.8 \%$ compared to the control (Table 1 ). This inhibitory potential of the E. dysenterica extract on the lettuce radicles has already been described in the literature (GIOTTO et al., 2007; MALHEIROS et al., 2016). Other species of Eugenia also show an inhibitory effect, such as the aqueous extract of Eugenia involucatra DC. (Cerejeira-do-mato), which promoted $42.6 \%$ inhibition in lettuce root growth (HÜLLER \& SCHOCK, 2011). According to Borella and Pastorini (2009), the roots are more sensitive to the action of substances present in the extracts compared to the other structures of the seedlings.

Tale 1 - Effect of the aqueous leaf extract of Eugenia dysenterica on the germination percentage (G\%), germination speed index (GSI), radicle growth (RG) and hypocotyls growth (HG) of lettuce cultivated in the laboratory

\begin{tabular}{|c|c|c|c|c|}
\hline & & Lettuce & & \\
\hline Aqueous extract & $\mathrm{G} \%$ & GSI & $\mathrm{RG}(\mathrm{cm})$ & $\mathrm{HG}(\mathrm{cm})$ \\
\hline $0 \mathrm{mg} \mathrm{L}^{-1}$ & $1.48 \mathrm{a}$ & $48.62 \mathrm{a}$ & $2.07 \mathrm{a}$ & $1.34 \mathrm{a}$ \\
\hline $250 \mathrm{mg} \mathrm{L}^{-1}$ & $1.46 \mathrm{a}$ & $48.25 \mathrm{a}$ & $0.78 \mathrm{~b}$ & $1.33 \mathrm{a}$ \\
\hline $500 \mathrm{mg} \mathrm{L}^{-1}$ & $1.45 \mathrm{a}$ & $46.54 \mathrm{a}$ & $0.56 \mathrm{~b}$ & $1.12 \mathrm{a}$ \\
\hline $1000 \mathrm{mg} \mathrm{L}^{-1}$ & $1.41 \mathrm{a}$ & $47.96 \mathrm{a}$ & $0.39 \mathrm{~b}$ & $0.81 \mathrm{~b}$ \\
\hline $2000 \mathrm{mg} \mathrm{L}^{-1}$ & $1.46 \mathrm{a}$ & $47.62 \mathrm{a}$ & $0.34 \mathrm{~b}$ & $0.61 \mathrm{~b}$ \\
\hline $4000 \mathrm{mg} \mathrm{L}^{-1}$ & $1.41 \mathrm{a}$ & $46.52 \mathrm{a}$ & $0.33 \mathrm{~b}$ & $0.57 \mathrm{~b}$ \\
\hline
\end{tabular}

Means followed by the same letter do not differ from one another by the Scott-Knott test $(p \leq 0.05)$

The hypocotyl growth of lettuce was also affected by the aqueous extractof E. dysenterica, in which an inhibitory effect was verified from the concentration of $1000 \mathrm{mg} \mathrm{L}^{-1}$, since the three highest concentrations promoted an average reduction of 50.5\% compared to the control. Reductions in lettuce hypocotyl using plant extracts from other species have also been reported in the literature in studies by Lima et al. (2011), who used ethanolic extract from the shoot of Bidens pilosa (black-jack), and Cândido et al. (2010) using the ethanol-water fraction of the ethanolic extract of Senna occidentalis (L.) Link (coffeeweed). These changes in the analyzed parameters in the present study prove the phytotoxic effect of the aqueous extract from dried leaves of E. dysenterica on lettuce seeds, since this is considered to be a bioindicator due to its sensitivity to several allelochemicals (FERREIRA \& BORGUETTI, 2004).

In relation to the germination percentage and the germination speed index of maize seeds, no significant difference 
between the concentrations used and the control were observed (Table 2). Araújo et al. (2011) also found no effect on these parameters when maize seeds were submitted to the ethanolic extract of Crotalaria juncea L. (Crotalaria) leaves. According to Peres et al. (2004), the germination takes place at the expense of seed reserves, therefore beingless sensitive to the presence of allelochemicals than seedling growth. Regarding primary root growth, only a concentration of $4000 \mathrm{mg}$ $\mathrm{L}^{-1}$ of the extract promoted inhibition, and a reduction of $43.8 \%$ was observed in relation to the control. This result was similar to that found by Malheiros et al. (2016), who observed a reduction in the primary root of maize at the concentration of $\left(4000 \mathrm{mg} \mathrm{L}^{-1}\right)$ of the ethanolic extract of E. dysenterica. In turn, the maize coleoptile had its growth affected by concentrations of $1000 \mathrm{mg} \mathrm{L}^{-1}$, in which an average reduction of $30 \%$ was observed in the higher concentrations of the aqueous extract of $E$. dysenterica (Table 2). This lower inhibition of maize coleotype in relation to the primary root can be explained by Linhares Neto et al. (2014); according to this author, greater effects on radicle/primary root growth may be related to the fact that the root is a characteristic anatomical structure which is more efficient to absorption. In line with this, Carvalho et al. (2016) reports that the root system is more sensitive to the action of allelochemicals due to the fact that root lengthening depends on cellular divisions, which will jeopardize the development if inhibited.

Table 2 - Effect of the aqueous leaf extract of Eugenia dysenterica on the germination percentage (G\%), germination speed index (GSI), primary root growth (PRG) and coleoptile growth (CG) of maize cultivated in the laboratory

\begin{tabular}{c|c|c|c}
\hline \multicolumn{3}{c}{ Maize } \\
\hline Aqueous extract & G\% & GSI & PRG (cm) \\
$0 \mathrm{mg} \mathrm{L}^{-1}$ & $1.40 \mathrm{a}$ & $24.00 \mathrm{a}$ & $7.90 \mathrm{a}$ \\
$250 \mathrm{mg} \mathrm{L}^{-1}$ & $1.29 \mathrm{a}$ & $23.00 \mathrm{a}$ & $6.92 \mathrm{a}$ \\
$500 \mathrm{mg} \mathrm{L}^{-1}$ & $1.38 \mathrm{a}$ & $2.46 \mathrm{a}$ & $2.36 \mathrm{a}$ \\
$1000 \mathrm{mg} \mathrm{L}^{-1}$ & $1.31 \mathrm{a}$ & $2.83 \mathrm{a}$ & $6.10 \mathrm{a}$ \\
$2000 \mathrm{mg} \mathrm{L}^{-1}$ & $1.29 \mathrm{a}$ & $2.46 \mathrm{a}$ & $6.28 \mathrm{a}$ \\
$4000 \mathrm{mg} \mathrm{L}^{-1}$ & $1.29 \mathrm{a}$ & $22.46 \mathrm{a}$ & $4.44 \mathrm{~b}$ \\
\hline
\end{tabular}

Means followed by the same letter do not differ from one another by the Scott-Knott test $(p \leq 0.05)$

The preliminary phytochemical analysis of E. dysenterica leaf extracts indicated the presence of several classes of secondary compounds, in which staining reactions were positive forphenols, hydrolysable tannins, flavonols, flavanones, flavanones, xanthones, flavones, free steroids and saponins. On the other hand, negative results were observed for condensed tannins, anthocyanins, anthocyanidins, chalcones, aurones, triterpenoids and quinones (Table 3 ).

Table 3 - Phytochemical analysis of theaqueous leaf extract of Eugenia dysenterica

\begin{tabular}{c|c}
\hline Secondary metabolite class & Result \\
\hline Phenols & + \\
\hline Condensed tannins & + \\
\hline Hydrolysable tannins & + \\
\hline Flavonols, flavanones, flavanonols and xanthones & + \\
\hline Flavones, flavonols and xanthones & + \\
\hline Flavonols & - \\
\hline Chalcones and auronas & - \\
\hline Free steroids & + \\
\hline Saponins & + \\
\hline Triterpenoids & - \\
\hline Quinones & - \\
\hline
\end{tabular}

\footnotetext{
+ Presence; - Absence
}

The results found are similar to those described in the literature. Couto et al. (2009) found the presence of different phenolic groups (tannins and flavonoids) in performing a phytochemical characterization of powder from dried E. dysenterica leaves collected in May 2007 in the Cerrado in Goiás. However, it is important to point out that the concentration of these compounds may differ within the same species, with changes in both the quality and the quantity of the chemical substances, since plant active principles are unstable and may vary depending on the geographical region, plant age, collection season, drying method and extraction method (CRUZ et al., 2000, SILVA et al., 2005). 
The classes of secondary compounds most associated with the allelopathic effect are generally phenolic compounds, flavonoids and tannins (TAIZ \& ZEIGER, 2017). Phenolic compounds comprise the largest group of metabolites identified as allelopathic (CARMO et al., 2007). Some studies have described that the presence of phenolic compounds is directly related to allelopathic activity, which can inhibit the growth and even the germination of other species belonging to the same environment (FIORENZA et al., 2016). Souto et al. (1994) verified that fragments of Pinus radiate D. Don and of Eucalyptus globules Labill. inhibited the growth and development of lettuce, and that this effect was related to the presence of phenolic compounds.

Flavonoids are present in plants in various forms and can inhibit plant and fungi growth, while tannins are involved in the process of plant protection against herbivores, invertebrates and vertebrates attacks, and are also excellent allelopathic agents (TAIZ \& ZEIGER, 2017). Rizvi and Rizvi (1992) reported phenolic acids, coumarins, polyphenols and flavonoids as the main allelochemicals responsible for photosynthesis inhibition, as they alter electron transport and phosphorylation in photosystems. In turn, saponins may interact with cell membranes and affect the photosynthetic process, thus influencing plant growth and development (WEIR et al., 2004).

Thus, the phytotoxic effect observed in this study is probably mainly due to the presence of phenolic compounds, tannins, flavonoids and saponins found in E. desynterica aqueous leaf extract. According to De conti and Franco (2011), allelopathic interferences are almost never caused by a single substance, and it is common to observe that their effect is the result of a set of secondary compounds, and the final response in the plant will depend on the additive and synergistic action between them.

\section{Conclusions}

The present study highlights that the aqueous leaf extract of Eugenia dysenterica found in the Cerrado Baiano has a phytotoxic effect, reducing the initial development of model species, and that these changes are possibly due to the presence of phenolic compounds, tannins, flavonoids and saponins in their leaves.

\section{References}

ARAÚJO EO, SANTANA CN, ESPÍRITO SANTO CL. Potencial alelopático de extratos vegetais de Crotalaria juncea sobre a germinação de milho e feijão. Rev. Bras. de Agroecologia. 2011;6(1):108-116.

BORELLA J, PASTORINI LH. Influência alelopática de Phytolacca dioica L. na germinação e crescimento inicial de tomate e picão-preto. Biotemas. 2009;22(3):67-75.

BRASIL. Regras para análise de sementes. Ministério da Agricultura Pecuária e Abastecimento/Secretaria da Defesa Agropecuária/coordenação Geral de Apoio Laboratorial, Brasília; 2009.

CÂNDIDO ACS, SCHMIDT V, LAURA VA, FACCENDA O, HESS SC, SIMIONATTO E,et al. Potencial alelopático da parte aérea de Senna occidentalis (L.) Link (Fabaceae, Caesalpinioideae): bioensaios em laboratório. Acta bot. bras. 2010;24(1):235-242.

CARMO FMS, BORGES EEL, TAKAKI M. Allelopathy of Brazilian sassafras (Ocotea odorifera (Vell.)) Rohwer aqueous extracts. Acta bot. bras. 2007;21(3):697-705.

CARVALHO WP, TEIXEIRA LGV, ABBADE NETO DO, MOREIRA JMS, CUNHA CEC. Alelopatia de resíduos de plantas de cobertura no controle de braquiária cv. Marandu. R. bras. Bioci. 2016;14(2):60-69.

CHENG F, CHENG Z. Research progress on the use of plant allelopathy in agriculture and the physiological and ecological mechanisms of allelopathy. Front Plant Sci. 2015;(6):1020.

COUTO RO, VALGAS AB, BARA MTF, PAULA JR. Caracterização físico-química do pó das folhas de Eugenia dysenterica DC. (Myrtaceae). Rev. Eletr. Farm. 2009;6(3):59-69.

CRUZ SEM, NOZAKI MH, BATISTA MA. Plantas medicinais e alelopatia. Rev. Biotec. Ciênc. Desenvol. 2000;3(15):28-34. 
DE CONTI D, FRANCO ETH. Efeito alelopático de extratos aquosos de Casearia sylvestris SW. na germinação e no crescimento de Lactuca sativa L. Rev. Bras. Agrociência. 2011;17(2-4):193-203.

FERNANDEZ C, MONNIER Y, SANTONJA M, GALLET C, WESTON LA, PRÉVOSTO B, SAUNIER, et al. The impact of competition and allelopathy on the trade-off between plant defense and growth in two contrasting tree species. Front Plant Sci. 2016;(7):594.

FERREIRA AG, ÁQUILA MEA. Alelopatia: uma área emergente da ecofisiologia. R. Bras. Fisiol. Veg. 2000;(12):175-204.

FERREIRA AG, BORGUETTI F. Germinação do básico ao aplicado. Artmed, Porto Alegre; 2004.

FERREIRA NR, MEDEIROS RB, SOARES GLG. Potencial alelopático do capim-annoni-2 (Eragrostisplana Nees) na germinação de sementes de gramíneas perenes estivais. Rev. Bras. Sementes. 2008;30(2):43-59.

FIORENZA M, DOTTO DB, BOLIGON AA, BOLIGON AA, ATHAYDE ML, VESTENA S. Análise fitoquímica e atividade alelopática de extratos de Eragrostis plana Nees (capim annoni). Iheringia. Sér. Botânica. 2016;71(2):193-200.

GIOTTO AC, OLIVEIRA SCC, SILVA JPG. Efeito alelopático de Eugenia dysenterica Mart. Ex DC. Berg. (Myrtaceae) na germinação e no crescimento de Lactuca sativa L. (Asteraceae). R. bras. Bioci. 2007;(5):600-602.

HÜLLER A, SCHOCK AA. Avaliação do potencial alelopático de três espécies de Eugenia L. (Myrtaceae) sobre o processo germinativo de Lactuca sativa L. Rev. Ciênc. Ambientais 2011;5(1):25-37.

LABOURIAU LG, VALADARES MB. On the germination of seeds of Calotropis procera (Ait.) Ait.f.An. Acad. Bras. Ciênc. 1976;48(2):263-284.

LIMA CP, CUNICO MM, MIGUEL OG, MIGUEL MD. Efeito dos extratos de duas plantas medicinais do gênero Bidens sobre o crescimento de plântulas de Lactuca sativa L. Rev. Ciênc. Farm. Básica Apl. 2011;32(1):83-87.

LINHARES NETO MV, MALHEIROS RSP, SANTANA FS, MACHADO LL, MAPELI AM. Avaliação alelopática de extratos etanólicos de Copaifera sabulicola sobre o desenvolvimento inicial de Lactuca sativa, Lycopersicum esculentum e Zea mays. Biotemas. 2014;27(3):23-32.

MAGUIRE JD. Speed of germination-aid in selection evaluation for seedling emergence and vigour. Crop Sci. 1962;2(2):176-177.

MALHEIROS RP, MAPELI AM, MACHADO LL. Atividades antioxidante e alelopática de extratos foliares obtidos de Eugenia dysenterica. Ciência e Natura. 2016;38(2):601-609.

MALHEIROS RSP, SANTANA FS, LINHARES NETO MV, MACHADO LL, MAPELI AM. 2014. Atividade alelopática de extratos de Lafoensia pacari A. ST.-HIL. sobre Lactuca sativa L. e Zea mays L. em condições de laboratório. Rev. Bras. Agroecologia. 2014;9(1):185-194.

MATOS FA. Introdução à fitoquímica experimental. Edições UFC, Fortaleza; 2009.

OLIVEIRA SCC, CAMPOS ML. Allelopathic effects of Solanum palinacanthum leaves on germination and seedling growth of Sesamum indicum. Allelopathy Journal. 2006;18(2):331-338.

OLIVEIRA SCC, FERREIRA AG, BORGHETTI F. Effects of Solanum lycocarpum fruit extract on sesame seed germination and seedling growth. Allelopathy Journal. 2004;13(2):201-210.

PERES MTLP, SILVA LB, FACCENDA O, HESS SC. 2004. Potencial alelopático de espécies de Pteridaceae (Pteridophyta). Acta bot. bras. 2004;18(4):723-730. 
PERIOTTO F, PEREZ SCJGA, LIMA MIS. Efeito alelopático de Andira humilis Mart. ex Benth na germinação e no crescimento de Lactuca sativa L. e Raphanus sativus L. Acta bot. bras. 2004;18(3):425-430.

PINA GO, BORGHETTI F, SILVEIRA CES, PEREIRA LAR. Effects of Eugenia desynterica leaf extracts on the growth of sesame and radish. Allelopathy Journal. 2009;23(2):313-322.

REIGOSA M, GOMES AS, FERREIRA AG, BORGHETTI F. Allelopathic research in Brazil. Acta Bot. Bras. 2013;(27);4:629-646.

RIZVI SJH, RIZVI V. Allelopathy: basic and applied aspects. London: Chapman \& Hall; 1992.

ROSADO LDS, RODRIGUES HCA, PINTO JEBP, CUSTÓDIO TN, PINTO LBB, BERTOLUCCI SKV. Alelopatia do extrato aquoso e do óleo essencial de folhas do manjericão "Maria Bonita" na germinação de alface, tomate e melissa. Rev. Bras. Plantas Med. 2009;11(4):422-228.

SAMPAIO BL, EDRADA-EBEL R, DA COSTA FB. Effect of the environment on the secondary metabolic profile of Tithonia diversifolia: a model for environmental metabolomics of plants. Sci Rep. 2016;(6):1-11.

SILVA FSE, AZEVEDO CAV. Versão do programa computacional Assistat para o sistema operacional Windows. Rev. Bras. Prod. Agroind. 2002;(4):71-78.

SILVA WW, BRITO AFS, MARINHO FA, MARINHO FA, RODRIGUES OG, ATHAYDE ACR. Ação do extrato alcoólico do capim santo (Cymbopogon citratus (DC.) Stapf) sobre nematóides gastrintestinais de ovinos. Agropecuária Científica no Semi-Árido. 2005;1(1): 46-49.

SOUTO XC, GONZALEZ L, REIGOSA MJ.Comparative analysis of allelopathic effects produced by four foresty species during decomposition process in their soils in Galicia (NW. Spain). J. Chem. Ecol. 1994;20(11):30053015.

TAIZ L, ZEIGER E. Fisiologia vegetal. 6 edição - Artmed, Porto Alegre; 2017.

WANDSCHEER ACD, PASTORINI LH. Interferência alelopática de Raphanus raphanistrum L. sobre a germinação de Lactuca sativa L. e Solanum lycopersicon L. Ciênc. Rural. 2008;38(4):949-953.

WEIR TL, PARK SW, VIVANCO JM. Biochemical and physiological mechanisms mediated by allelochemicals. Curr. Opin. Plant Biol. 2004;7(4):472-479. 